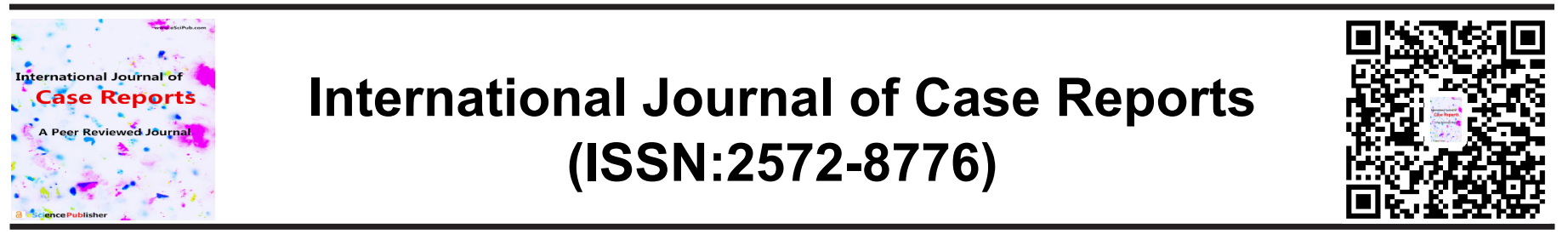

\title{
Paget's disease of bone in a patient on peritoneal dialysis
}

Flores-Padilla Guillermo ${ }^{1,2}$, Solis Jose Gabriel ${ }^{1,3^{*}}$, Zavala-Jonguitud Luis Fernando ${ }^{1,4}$, JuarezVilla Daniel $^{1,5}$, Olascoaga-Lugo Arturo ${ }^{1,6}$

${ }^{1}$ Department of Internal Medicine, Hospital de Especialidades, Centro Médico Nacional Siglo XXI, Instituto Mexicano del Seguro Social. México City, México. Adress: Avenida Cuauhtémoc \# 330 Colonia Doctores. Alcaldía Cuauhtémoc. Ciudad de México 06725. México. ${ }^{2}$ ORCID ID: https:// orcid.org/0000-0003-0697-620X ${ }^{3}$ ORCID ID: https://orcid.org/0000-0003-3532-6062 ${ }^{4}$ ORCID ID: https://orcid.org/0000-0002-6405-7810 5 ORCID ID: https://orcid.org/0000-0002-6462-8935 ${ }^{6}$ ORCID ID: https://orcid.org/0000-0002-6557-7180

\section{ABSTRACT}

Paget's disease of bone is a disorder characterized by disorganized bone remodeling. It's occurrence in patients with end-stage kidney disease on renal replacement therapy is rare. Here we report a case of Paget's disease of bone in an 80-yearold male on peritoneal dialysis that presented a high level of alkaline-phosphatase with a mildly elevated parathyroid hormone level and typical imaging findings localized to the pelvis. This is the fourth reported case of Paget's disease in a patient on peritoneal dialysis and the first treated with denosumab.

*Correspondence to Author:

Solis Jose Gabriel

Department of Internal Medicine, Hospital de Especialidades, Centro Médico Nacional Siglo XXI, Instituto Mexicano del Seguro Social. México City, México. Phone: +52 1868 1570701; Adress: Avenida Cuauhtémoc \# 330 Colonia Doctores. Alcaldía Cuauhtémoc. Ciudad de

Keywords: Paget disease of bone; kidney failure; peritoneal México 06725. México. dialysis; denosumab

How to cite this article:

Flores-Padilla Guillermo, Solis Jose Gabriel, Zavala-Jonguitud Luis Fernando, Juarez-Villa Daniel, Olascoaga-Lugo Arturo. Paget's disease of bone in a patient on peritoneal dialysis. International Journal of Case Reports, 2021; 5:196.

\section{eScîPPub}

eSciPub LLC, Houston, TX USA. Website: http://escipub.com/ 


\section{Introduction}

Paget disease of bone is a chronic disorder characterized by focal areas of increased and disorganized bone remodeling affecting one or more bones throughout the skeleton leading to disturbance of bone micro and macroarchitecture [1, 2]. There is overactivity of both osteoblast and osteoclasts, resulting in either deposition of low-quality "woven" bone or areas of osteolysis, respectively. ${ }^{[3]}$. Both can result in reduced bone strength, leading to complications of deformity, arthritis, neurological sequelae and fracture. The occurrence of Paget's disease in patient with chronic renal failure is a probably underdiagnosed entity and so far this is the eighth reported case [4-11]. A correct imaging diagnosis is fundamental and has important therapeutic implications. Herein, we describe a patient on peritoneal dialysis that was referred for perioperative care with an elevated serum level of alkaline phosphatase and finally diagnosed with Paget's disease of bone restricted to the pelvis.

\section{Case report}

An 80-year-old male who had been on peritoneal dialysis was referred by his orthopedic surgeon to our perioperative-care clinic for an elective hip replacement surgery. His chronic renal failure

was secondary to nephroangiosclerosis diagnosed 15 years before and started long term peritoneal dialysis for the last 10 years. He was being treated with amlodipine, atorvastatine, calcitriol three times a day and during the last year calcium carbonate. On physical examination, the patient had no organ specific symptoms except for pain on the left side of the pelvis that limited his ability to walk and climb stairs without assistance. Complete blood count showed hemoglobin $11.4 \mathrm{~g} / \mathrm{dL}$, hematocrit $35 \%$, white blood cell count $5500 \times 10^{9} / \mathrm{L}$ and platelet count of $245 \times 10^{9} / \mathrm{L}$. Serum biochemistry results we are follows: creatinine, $7.2 \mathrm{mg} / \mathrm{dL}$; blood urea nitrogen, $77 \mathrm{mg} / \mathrm{dL}$; calcium, $9.2 \mathrm{mg} / \mathrm{dL}$; phosphorus, $4.2 \mathrm{mg} / \mathrm{dL}$; alkaline phosphatase, $4500 \mathrm{U} / \mathrm{L}$, alanine aminotransferase, $33 \mathrm{U} / \mathrm{L}$; aspartate aminotransferase, $38 \mathrm{U} / \mathrm{L}$; intact parathyroid hormone $73 \mathrm{pg} / \mathrm{mL}(10-65 \mathrm{pg} / \mathrm{mL})$. Three months before, a pelvis $x$-ray showed a hazy sclerotic area on the left side (Figure 1A). At that time, a CT-scan of pelvis revealed a thickened disorganized cortex, osteosclerosis and deformity of the pelvic left ileum. Wholebody scan with thecnetium-99-hidroxi-methilinedi-phosphnate showed intense asymmetric heterogenous uptake on the left side of the pelvis with area of ionic bone remodeling on the left ileum bone (Figure 1B-D).

Figure 1: Imaging studies of the patient.

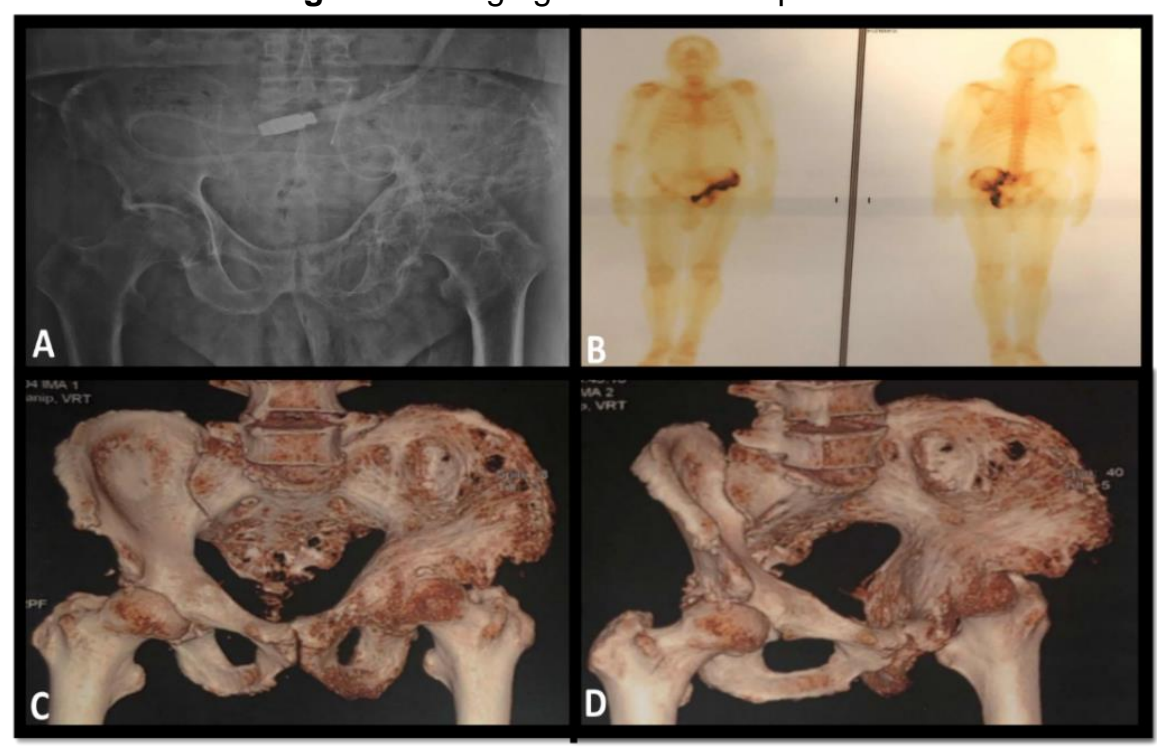

Figure 1. A. X-ray that shows a sclerotic pattern lesion in the pelvis with thickening of cortical bone and heightened trabecular markings. B-D. Bone scintigraphy that shows intense heterogeneous uptake of the radionuclide at the pagetic lesion. 
Considering the patient's condition treatment with bisphosphonates was contraindicated, therefore, he received treatment with Denosumab. He is currently being followed to evaluate his condition.

\section{Discussion}

Paget's disease of bone is a non-malignant skeletal disorder characterized by focal abnormalities in bone remodeling at one (monostotic) or more (polyostotic)skeletal sites. Almost any bone can be affected but there is a predilection for the pelvis, spine, femur, tibia, and skull. It is more common in males, and in certain ethnic groups. Whites Europeans are most commonly affected ${ }^{[12]}$.
The prevalence of this disease in patients with advanced renal failure in uncertain, with only 8 cases reported before ours [4-11]. 4 of these cases were patients on hemodialysis ${ }^{[5-8]}$ and only three on peritoneal dialysis ${ }^{\left[{ }^{-11}\right]}$. Age ranged from 48 to 83 years-old, time on dialysis ranged 3 months to 6 years, most patients had the monostotic variety that involved pelvis, skull, or vertebrae. In three of the cases on hemodialysis, secondary hyperparathyroidism masked the diagnosis of Paget's disease of bone, which became evident after parathyroidectomy. Of the cases on peritoneal dialysis, two had the polyostotic variety and secondary hyperparathyroidism. [Table 1]

Table 1. Reported cases of Paget's disease in patients with chronic kidney disease on peritoneal dialysis

\begin{tabular}{|c|c|c|c|c|c|c|}
\hline $\begin{array}{l}\text { Author. } \\
\text { Year }\end{array}$ & Gender/Age & $\begin{array}{l}\text { Time of } \\
\text { peritoneal } \\
\text { dialysis }\end{array}$ & $\begin{array}{l}\text { Clinical and } \\
\text { biochemical } \\
\text { features }\end{array}$ & $\begin{array}{l}\text { Radiologic } \\
\text { diagnosis }\end{array}$ & $\begin{array}{l}\text { Secondary } \\
\text { hyperparathyroidism }\end{array}$ & Treatment \\
\hline $\begin{array}{l}\text { Wu LC. Et al. } \\
2009 .\end{array}$ & $\mathrm{F} / 77$ & 3 months & $\begin{array}{l}\text { Monostotic. } \\
\text { Bone pain. } \\
\text { Lumbar } \\
\text { spine. }\end{array}$ & X-Ray. MRI. & No data. & $\begin{array}{l}\text { Calcitonin. } \\
\text { Surgical } \\
\text { decompressior }\end{array}$ \\
\hline $\begin{array}{l}\text { De Sousa- } \\
\text { Amorim E et } \\
\text { al. } 2012 \text {. }\end{array}$ & $\mathrm{M} / 72$ & 3 years & $\begin{array}{l}\text { Polyostotic. } \\
\text { lliac, spine, } \\
\text { long bones. } \\
\text { Elevated AP } \\
\text { and PTH. }\end{array}$ & $\begin{array}{l}\text { X-Ray. CT. } \\
\text { Bone } \\
\text { scintigraphy. }\end{array}$ & Yes & None \\
\hline $\begin{array}{l}\text { Panuccio } \\
\text { VA. } 2020^{11}\end{array}$ & $\mathrm{M} / 60$ & $\begin{array}{l}\text { Started after } \\
\text { diagnosis of } \\
\text { PD }\end{array}$ & $\begin{array}{l}\text { Polyostotic. } \\
\text { Long bones. } \\
\text { Elevated AP } \\
\text { and PTH. }\end{array}$ & X-Ray & Yes & $\begin{array}{l}\text { Biphophonate. } \\
\text { Calcitonin. } \\
\text { Vitamin D. }\end{array}$ \\
\hline $\begin{array}{l}\text { Flores } G \text { et } \\
\text { al. }\end{array}$ & $\mathrm{M} / 80$ & 10 years & $\begin{array}{l}\text { Monostotic. } \\
\text { lliac. Bone } \\
\text { pain. } \\
\text { Elevated AP. }\end{array}$ & $\begin{array}{l}\text { X-Ray. Bone } \\
\text { scintigraphy. }\end{array}$ & No & Denosumab. \\
\hline
\end{tabular}

Table 1. Of the reported cases of Paget's disease of bone, two had polyostotic disease and hyperparathyroidism. There is wide variability in treatment. AP: Alkaline phosphate. PTH: Parathyroid hormone. CT: Computed tomography. MRI: Magnetic resonance imaging. PD: Paget's disease

In our patient a high level of alkaline phosphatase suggested a persistent high turnover bone remodeling disease, while the intact parathyroid hormone was in the upper limit suggesting the diagnosis of secondary hyperparathyroidism. Findings on X-rays, CTscan and whole-body scan ruled out bone metastasis, malignancies and renal osteodystrophy making the diagnosis of Paget's disease of bone the most likely cause of bone disease.

Treatment has been with anti-osteoclast drugs, initially calcitonin and more recently bisphosphonates. In cases of kidney disease with low glomerular filtration rate, bisphosphonates are contraindicated ${ }^{[3,4]}$. Due 
to the risk of further reduction of further kidney function or end-stage kidney failure other effective treatments are recommended. Denosumab, a human monoclonal antibody against RANKL, reversibly inhibits osteoclastmediated bone resorption and has been used in two cases of Paget's disease of bone in patients on dialysis with good results ${ }^{[3,4]}$. This is the first reported case of a patient with Paget's disease on peritoneal dialysis treated with denosumab.

Conflicts of Interest: The authors declare no conflict of interest.

Ethical issues: All procedures performed in studies involving human participants were in accordance with the ethical standards of the institutional and/or national research committee at which the studies were conducted and with the 1964 Helsinki declaration and its later amendments or comparable ethical standards.

Informed consent: Informed consent to publish this manuscript was signed by the patient and first-degree relatives.

Funding: The authors had no funding for the development of this report.

Others: An abstract of this paper was presented at the Mexico's XLII National Congress of Internal Medicine 2019.

Data availability: Not applicable.

Code availability: Not applicable.

\section{References}

[1] Ralston SH, Corral-Gudino L, Cooper C, Francis RM, Fraser WD, Gennari L, et al. Diagnosis and Management of Paget's Disease of Bone in Adults: A Clinical Guideline. J Bone Miner Res. 2019;34(4):579-604.

[2] Ralston SH. Clinical practice. Paget's disease of bone. N Engl J Med. 2013;368(7):644-50.

[3] Reid IR, Sharma S, Kalluru R, Eagleton C. Treatment of Paget's Disease of Bone with Denosumab: Case Report and Literature Review. Calcif Tissue Int. 2016;99(3):322-5.

[4] Schwarz $P$, Rasmussen $A Q$, Kvist $T M$, Andersen UB, Jorgensen NR. Paget's disease of the bone after treatment with Denosumab: a case report. Bone. 2012;50(5):1023-5.

[5] Lorho R, Mourad G, Couret I, Argiles A. The dialysis patient with persisting elevation of bone alkaline phosphatase after parathyroidectomy. Nephrol Dial Transplant. 1998;13(9):2394-6.

[6] Cianciolo G, La Manna G, Capelli I, Donati G, Persici E, Cuna V, et al. A case of Paget's disease in hemodialysis. Clin Nephrol. 2010;73 (5):403-7.

[7] Ringe JD, Delling G. [Unusual course of renal osteopathy with Paget's disease and aluminum deposits]. Dtsch Med Wochenschr. 1985;110 (11):411-5.

[8] Etemadi J, Bagheri N, Falaknazi K, Ardalan M, Rahbar K, Nobakht Haghighi A, et al. Paget's disease of bone in a patient on hemodialysis. Iran J Kidney Dis. 2008;2(2):105-7.

[9] Wu LC, Tseng $\mathrm{CH}$, Chiang YF, Tsuang $\mathrm{YH}$. Monostotic Vertebral Paget's Disease of the Lumbar Spine. J Chin Med Assoc. 2009;72 (1):52-5.

[10] De Sousa-Amorim E, Del Peso-Gilsanz G, BajoRubio MA, Selgas-Gutierrez R. Asymptomatic polyostotic Paget's disease associated with secondary hyperparathyroidism in a peritoneal dialysis patient. Nefrologia. 2012;32(4):542-4.

[11] Panuccio VA, Tripepi R. Paget's disease and secondary hyperparathyroidism: is healing possible?. Frontiers in cell and developmental biology. 2020;8:1-3.

[12] van Staa TP, Selby P, Leufkens HG, Lyles K, Sprafka JM, Cooper C. Incidence and natural history of Paget's disease of bone in England and Wales. J Bone Miner Res. 2002;17(3):46571.

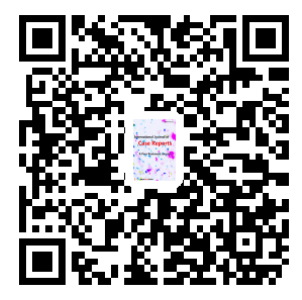

